\title{
ACTEOSIDE AND RELATED PHENYLETHANOID GLYCOSIDES IN BYBLIS LINIFLORA SALISB. PLANTS PROPAGATED IN VITRO AND ITS SYSTEMATIC SIGNIFICANCE
}

\author{
JAN SCHLAUER ${ }^{1}$, JAROMIR BUDZIANOWSKI ${ }^{2}$, \\ KRYSTYNA KUKUŁCZANKA ${ }^{3}$, LIDIA RATAJCZAK ${ }^{2}$ \\ ${ }^{1}$ Institute of Plant Biochemistry, University of Tübingen \\ Corrensstr. 41, 72076 Tübingen, Germany \\ 2 Department of Pharmaceutical Botany, University of Medical Sciences in Poznań \\ Św. Marii Magdaleny 14, 61-861 Poznań, Poland \\ ${ }^{3}$ Botanical Garden, University of Wrocław \\ Sienkiewicza 23, 50-335 Wrocław, Poland
}

(Received: May 30, 2003. Accepted: February 4, 2004)

\begin{abstract}
From plantlets of Byblis liniflora Salisb. (Byblidaceae), propagated by in vitro culture, four phenylethanoid glycosides - acteoside, isoacteoside, desrhamnosylacteoside and desrhamnosylisoacteoside were isolated. The presence of acteoside substantially supports a placement of the family Byblidaceae in order Scrophulariales and subclass Asteridae. Moreover, the genera containing acteoside are listed; almost all of them appear to belong to the order Scrophulariales.
\end{abstract}

KEY WORDS: Byblis liniflora, Byblidaceae, Scrophulariales, chemotaxonomy, phenylethanoid glycosides, acteoside, in vitro propagation.

\section{INTRODUCTION}

Byblidaceae are a small family of essentially Western and Northern Australian (extending to Papuasia) herbs with exstipulate, linear sticky leaves spirally arranged along a more or less upright or sprawling stem and solitary, ebracteolate, pentamerous, weakly sympetalous, very weakly zygomorphic (stamens and style slightly bent) flowers in the axils of the upper leaves. Pollen is shed as individual grains with smooth exine. The superior ovary is 2-locular with a single style terminating in a knob-shaped stigma, the axile placentas bear numerous unitegmic ovules. Chalazal and micropylar endosperm haustoria are present. Chromosome counts of $2 n=14,2 n=16,2 n=18,2 n=24$, and $2 n=32$ have been reported (Conran et al. 2002a). Fossils are unknown.

The only genus of the family Byblidaceae - Byblis Salisb. was described for the first time by English botanist and gardener - R.A. Salisbury in "The Paradisus Londinensis" in 1808 (Fessler 1982) and until recently it involved only two species $-B$. liniflora Salisb. and B. gigantea Lindl., but Lowrie and Conran (1998) and Conran et al. (2002b) established four new species $-B$. aquatica Lowrie et Conran, B. filifolia Planch, B. rorida Lowrie et Conran, and $B$. lamellata Conran et Lowrie.

Byblis liniflora Salisb. grows erect to $15-20 \mathrm{~cm}$. Its leaves are alternate, involute in vernation, simple, linear with a clavate apical swelling, and with stipitate, adhesive and sessile, digestive glands on the lamina (Huxley et al. 1992; Lowrie 1998). The species is an annual in its native habitats where soils dry out part of the year. In situations of permanently wet soils it is a perennial (Pietropaolo and Pietropaolo 1996).

The chemical composition of Byblis is rather hardly known. Absence of naphthoquinones recorded for B. gigantea supported the assumption that Byblidaceae are not related to Droseraceae (Zenk et al. 1969; Juniper et al. 1989).

Here we present our phytochemical investigations on $B y$ blis liniflora obtained by in vitro culture, which led to isolation and identification of four phenylethanoid glycosides for the first time found in the family Byblidaceae. One of them - acteoside (verbascoside) was previously found in numerous species including many medicinal plants; it is also known for many biological activities and generally considered as important chemotaxonomic marker (Jimenez and Riguera 1994). For the latter reason we discuss the sy- 
stematic significance of acteoside in Byblidaceae and other taxa containing this compound.

\section{MATERIAL AND METHODS}

\section{General}

UV spectra were recorded in methanol on a Specord M40 (Zeiss,Jena) using previously described procedures (Mabry et. al. 1970). NMR spectra were recorded on Varian Unity 300, at $300 \mathrm{MHz}$ for ${ }^{1} \mathrm{H}$ NMR and $75 \mathrm{MHz}$ for ${ }^{13} \mathrm{C}$ NMR, in $\mathrm{CD}_{3} \mathrm{OD}$ solutions with TMS as internal standard. Analytical thin-layer chromatography (TLC) was carried out on pre-coated silica gel and cellulose plastic-backed sheets (Merck, Darmstadt) and self-made polyamide (Woelm, Eschwege, Germany) or polyamide DC6 (Macherey-Nagel, Düren) plates. For detection, the developed chromatograms were viewed under $\mathrm{UV}_{365 \mathrm{~nm}}$ and $\mathrm{UV}_{254 \mathrm{~nm}}$ before and after spraying with $0.1 \%$ Naturstoffreagenz A (NA) or $1 \%$ aluminium chloride in ethanol followed by warming. Preparative thin layer chromatograhy (PTLC) was performed on self-made polyamide (Woelm, Eschwege) and $\mathrm{PF}_{254}$ silica gel (Merck, Darmstadt) $(0.5$ or $1 \mathrm{~mm}$ thickness) plates. Open column chromatography (CC) was carried out with polyamide SC-6 (Macherey-Nagel, Düren) and Sephadex LH-20 (Pharmacia, Uppsala).

\section{Plant material}

In vitro cultured plantlets of Byblis liniflora Salisb. were originally received from the Micropropagation Unit of Royal Botanic Gardens, Kew, United Kingdom, in 1987.

\section{In vitro cultures}

RM medium (Reinert and Mohr 1967) and MS medium (Murashige and Skoog 1962) with half-strength concentration of mineral salts (1/2 MS) were used. Initial explants shoots and nodal segments - were taken from plantlets of Byblis liniflora. Response to auxin - IBA (1 mg/l), alone or in combination with cytokinins - kinetin (1-2 mg/l) and/or BA $(0.5-1 \mathrm{mg} / \mathrm{l})$ was investigated with single shoot fragments placed in small test tubes (20 explants per each experiment). For further mass-propagation, the aggregates consisting of 2-3 shoots with callus tissue formed at the ba-

TABLE $1 .{ }^{1} \mathrm{H}$ and ${ }^{13} \mathrm{C}$ NMR data for phenethylethanoid glycosides from Byblis liniflora.

\begin{tabular}{|c|c|c|c|c|c|c|c|c|}
\hline \multirow{2}{*}{ Position } & \multicolumn{2}{|r|}{1} & \multicolumn{2}{|r|}{2} & \multicolumn{2}{|r|}{3} & \multicolumn{2}{|r|}{4} \\
\hline & ${ }^{13} \mathrm{C}$ & ${ }^{1} \mathrm{H}$ & ${ }^{13} \mathrm{C}$ & ${ }^{1} \mathrm{H}$ & ${ }^{13} \mathrm{C}$ & ${ }^{1} \mathrm{H}^{*}$ & ${ }^{13} \mathrm{C}$ & ${ }^{1} \mathrm{H}$ \\
\hline \multicolumn{9}{|l|}{ aglycone } \\
\hline 1 & 131.5 & & 131.5 & & 131.5 & & 131.6 & \\
\hline 2 & 117.1 & $6.71 d(2.1)$ & 117.1 & $6.67 d(1.8)$ & 117.2 & $6.67 d(2.1)$ & 116.6 & $6.69 d(2.1)$ \\
\hline 3 & 146.1 & & 146.8 & & 146.2 & & 146.2 & \\
\hline 4 & 144.6 & & 144.7 & & 144.7 & & 144.7 & \\
\hline 5 & 116.4 & $6.70 d(8.4)$ & 116.4 & $6.63 d(8.1)$ & 116.4 & $6.63 d(8.1)$ & 117.2 & $6.67 d(8.1)$ \\
\hline 6 & 121.3 & $6.57 d d(2.1 / 8.4)$ & 121.3 & $6.53 d d(1.8 / 8.1)$ & 121.3 & $6.53 d d(2.1 / 8.1)$ & 121.3 & $6.56 d d(1.8 / 8.1)$ \\
\hline 7 & 36.5 & $2.79 t(9.6)$ & 37.1 & $2.79 t(7.2)$ & 36.7 & $2.79 t(7.5)$ & 36.6 & $2.80 t(7.2)$ \\
\hline 8 & 72.33 & $4.05 \mathrm{~m}$ & 72.4 & $4.05 \mathrm{~m}$ & 72.4 & $3.96 \mathrm{~m}$ & 72.3 & $4.03 \mathrm{~m}$ \\
\hline & & $3.74 m$ & & $3.71 \mathrm{~m}$ & & $3.71 \mathrm{~m}$ & & $3.74 m$ \\
\hline \multicolumn{9}{|l|}{ caffeoyl } \\
\hline $1^{\prime}$ & 127.7 & & 127.8 & & 127.8 & & 127.8 & \\
\hline $3^{\prime}$ & 146.8 & & 146.4 & & 146.8 & & 146.9 & \\
\hline $4^{\prime}$ & 149.8 & & 149.6 & & 149.7 & & 149.8 & \\
\hline $5^{\prime}$ & 116.6 & $6.79 d(8.1)$ & 116.6 & $6.76 d(8.1)$ & 116.6 & $6.76 d(8.4)$ & 116.4 & $6.76 d(8.1)$ \\
\hline $6^{\prime}$ & 123.3 & $6.89 d d(2 / 8.1)$ & 123.2 & $6.89 d d(2 / 8.1)$ & 123.2 & $6.88 d d(2.1 / 8.4)$ & 123.1 & $6.96 d d(1.8 / 8.1)$ \\
\hline $7^{\prime}$ & 148.1 & $7.56 d(15.9)$ & 147.5 & $7.56 d(15.9)$ & 147.3 & $7.56 d(15.9)$ & 147.7 & $7.59 d(15.9)$ \\
\hline $8^{\prime}$ & 115.3 & $6.28 d(15.9)$ & 115.2 & $6.29 d(15.9)$ & 115.0 & $6.28 d(15.9)$ & 115.3 & $6.30 d(15.9)$ \\
\hline $9^{\prime}$ & 168.4 & & 169.2 & & 169.2 & & 168.7 & \\
\hline \multicolumn{9}{|l|}{ glucose } \\
\hline 1, & 104.2 & $4.38 d(7.8)$ & 104.5 & $4.33 d(7.5)$ & 104.6 & $4.33 d(7.8)$ & 104.5 & $4.36 d(7.8)$ \\
\hline 2, & 76.2 & $3.40 d d(7.8 / 9.3)$ & 75.8 & $* *$ & 75.1 & $3.21 d d(7.8 / 8.7)$ & 75.3 & $* *$ \\
\hline $3^{\prime \prime}$ & 81.7 & $3.82 t(9.3)$ & 84.1 & $* *$ & 78.0 & $3.40-3.34 m$ & 75.9 & $* *$ \\
\hline 4, & 70.4 & $4.94 t(9.6)$ & 70.1 & $* *$ & 71.8 & $3.40-3.34 \mathrm{~m}$ & 72.6 & $4.84 t(9.6)$ \\
\hline $5^{\prime,}$ & 76.0 & $3.60-3.50 \mathrm{~m}$ & 75.5 & $* *$ & 75.5 & $3.52 \mathrm{~m}$ & 76.2 & $* *$ \\
\hline 6, & 62.3 & $3.60-3.50 \mathrm{~m}$ & 64.7 & $4.49 d d(1.9 / 11.4)$ & 64.7 & $4.50 d d(2.1 / 12.0)$ & 62.5 & $* *$ \\
\hline & & $3.60-3.50 \mathrm{~m}$ & & $4.35 d d(5.7 / 11.4)$ & & $4.33 d d(6.0 / 12.0)$ & & \\
\hline \multicolumn{9}{|l|}{ rhamnose } \\
\hline $1,$, & 103.0 & $5.19 d(1.5)$ & 102.8 & $5.18 d(1.3)$ & & & & \\
\hline $2,$, & 72.28 & $3.93 d d(1.5 / 3.3)$ & 72.47 & $* *$ & & & & \\
\hline $3,$, & 72.0 & $3.60-3.50 \mathrm{~m}$ & 72.3 & $* *$ & & & & \\
\hline $4,$, & 73.8 & $3.30 t(9.6)$ & 74.0 & $* *$ & & & & \\
\hline $5,$, & 70.6 & $3.60-3.50 \mathrm{~m}$ & 70.5 & $* *$ & & & & \\
\hline $6, "$ & 18.5 & $1.09 d(6.0)$ & 17.9 & $1.24 d(6.0)$ & & & & \\
\hline
\end{tabular}

* signals sequenced by ${ }^{1} \mathrm{H}-{ }^{1} \mathrm{H}-\mathrm{COSY}$ spectrum

** signal pattern unclear due to overlap 
sal part of shoots were placed onto a fresh RM medium every 2-3 months in $200 \mathrm{ml}$ Erlenmayer flasks. The cultures were maintained in a growth chamber at $22-24^{\circ} \mathrm{C}$ with $24 \mathrm{~h}$ light of $30 \mu \mathrm{M} \times \mathrm{m}^{-2} \times \mathrm{s}^{-1}$.

\section{Plant material for phytochemical analyses}

The plantlets of B. liniflora obtained on RM medium were harvested in August 1995.

\section{Extraction and isolation of phenylethanoid glycosides 1-4.}

The fresh, whole plants (246 g) were plunged into boiling methanol (1L) and left for maceration at ambient temperature, which was repeated twice and lasted six months in total. The methanol extract was concentrated to dryness in vacuo, suspended in water $(40 \mathrm{ml})$ and extracted with chloroform $(3 \times 100 \mathrm{ml})$ and 1-butanol saturated with water $(5 \times 50 \mathrm{ml})$. The evaporated in vacuo butanolic fraction (1.9 g) was separated over Sephadex LH20 column by sequential elution with 50\%, 80\% and 100\% methanol to give 15 fractions. Fraction 10 yielded compound 1 (361.2 mg), after PTLC on polyamide in chloroform-methanol-butanone-2-acetyloacetone $(9: 4: 2: 1)$, followed by CC on Sephadex LH20 with methanol. Fraction 12, was separated by PTLC on silica gel in ethyl acetate-ethanol-water $(30: 3: 2)$ to afford compounds: 2 (7.6 mg), $3(25.1 \mathrm{mg})$ and 4 (7.4 $\mathrm{mg}$ ), after final purification by $\mathrm{CC}$ on polyamide and $\mathrm{Se}-$ phadex LH20 in methanol, respectively.

acteoside (=verbascoside) (1)

UV: $\lambda$ (nm): MeOH: 248, 292, 335; $+\mathrm{AlCl}_{3}: 263,298$, 365. ${ }^{1} \mathrm{H}$ and ${ }^{13} \mathrm{C}$ NMR: Table 1.

\section{isoacteoside (2)}

UV: $\lambda(\mathrm{nm}): \mathrm{MeOH}: 248,291,330 ;+\mathrm{AlCl}_{3}: 257 \mathrm{sh}, 296$, 350. ${ }^{1} \mathrm{H}$ and ${ }^{13} \mathrm{C}$ NMR: Table 1.

\section{desrhamnosyl isoacteoside (3)}

$\mathrm{UV}: \lambda(\mathrm{nm}): \mathrm{MeOH}: 247 \mathrm{sh}, 291,329 ;+\mathrm{AlCl}_{3}: 257 \mathrm{sh}$, 296, 350. ${ }^{1} \mathrm{H}$ and ${ }^{13} \mathrm{C}$ NMR: Table 1.

\section{desrhamnosyl acteoside (4)}

UV: $\lambda(\mathrm{nm}): \mathrm{MeOH}: 247 \mathrm{sh}, 291,330 ;+\mathrm{AlCl}_{3}: 260 \mathrm{sh}$, 299, 359. ${ }^{1} \mathrm{H}$ and ${ }^{13} \mathrm{C}$ NMR: Table 1.

\section{RESULTS AND DISCUSSION}

Efficient growth, proliferation and rooting of plantlets of $B$. liniflora in in vitro conditions was obtained on the basal RM medium and 1/2 MS medium. Supplementation of the RM medium with growth regulators slightly improved shoot propagation from initial explants when BA was used (approximately from 7 to 12 shoots per explant). However, the best explants for mass propagation were aggregates consisting of 2-3 shoots with the green-white callus tissue formed at their base part from which adventitious shoots regenerated (approximately 20 shoots per explant) within 2-3 months of culture. Therefore, one can conclude that basal RM medium is satisfactory for mass propagation of $B$. liniflora. Efficient propagation in in vitro culture on RM or MS media without exogenous growth regulators have been earlier observed in the case of other carnivorous species like those of the genera Drosera and Dionaea of the family
Droseraceae (Kukułczanka 1991; Kukułczanka and Budzianowski 2002). Similarly, stem cuttings of Byblis liniflora can be rooted in vivo (Fessler 1982; Slack 1985; Huxley et al. 1992).

The methanol extract of the fresh plantlets of Byblis liniflora obtained on RM medium was separated into chloroform, butanol and water soluble fractions. Preliminary analyses by thin-layer chromatography on silica gel of the chloroform fraction, according to Budzianowski (1995), showed absence of naphthoquinones (plumbagin or 7-methyljuglone) previously also reported for Byblis gigantea (Juniper et. al. 1989), whereas two-dimensional thin-layer chromatography (2D TLC) on cellulose (Budzianowski and Skrzypczak 1995) of butanolic and water fractions, suggested presence of caffeic acid derivatives in butanol fraction. The latter was separated by combination of column and thin layer chromatography to afford compounds 1-4. The isolates exhibited very similar UV spectra with bathochromic shift with aluminium chloride $\left(\mathrm{AlCl}_{3}\right)$, indicative of the free ortho-diphenolic grouping, and were typical for the caffeic acid esters (Harborne 1984). The chemical structures of compounds 1-4 (Fig. 1) were identified by comparison of their ${ }^{1} \mathrm{H}$ and ${ }^{13} \mathrm{C}$ NMR data (Table 1) with those published in the literature as: acteoside (verbascoside) (1) (Budzianowski and Skrzypczak 1995; Debrauwer et. al. 1989; Xiong et. al. 1996), isoacteoside (isoverbascoside) (2) (Kobayashi et.al. 1987), desrhamnosylisoacteoside (calceolarioside B) (3) (Shimomura et al. 1987) and desrhamnosylacteoside (calceolarioside A) (4) (Nishimura et. al. 1991). The ${ }^{13} \mathrm{C}$ NMR assignments of resonances for carbon atoms C-2, C-3, C-5 of aglycone moieties as well as those for C-3', C-4' and C-8' of caffeoyl acyl groups, pre-

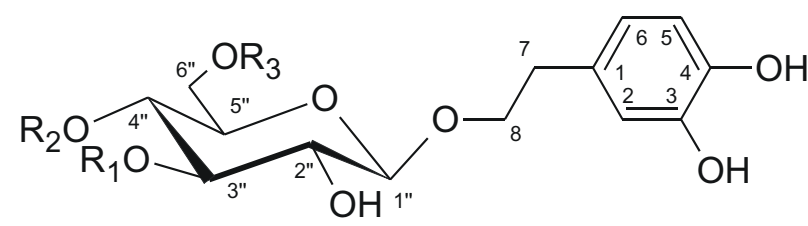

$\begin{array}{llll} & \mathrm{R}_{1} & \mathrm{R}_{2} & \mathrm{R}_{3} \\ \mathbf{1} & \text { rhamnosyl } & \text { caffeoyl } & \mathrm{H} \\ \mathbf{2} & \text { rhamnosyl } & \mathrm{H} & \text { caffeoyl } \\ \mathbf{3} & \mathrm{H} & \mathrm{H} & \text { caffeoyl } \\ \mathbf{4} & \mathrm{H} & \text { caffeoyl } & \mathrm{H}\end{array}$

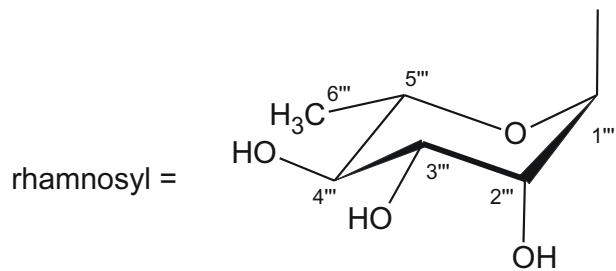

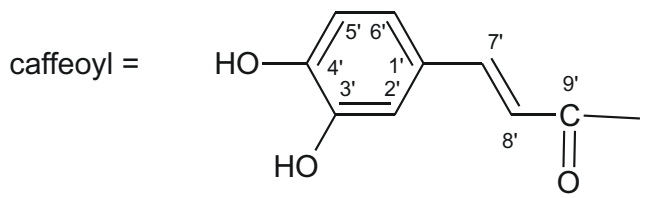

Fig. 1. Chemical structures of phenylethanoid glycosides isolated from Byblis liniflora. 
TABLE 2. Plant genera in which acteoside has been detected (classification following Bremer et al. 2002 with nomenclatural adjustments.)

\begin{tabular}{|c|c|c|c|c|c|}
\hline $\begin{array}{l}\text { Order } \\
\text { Family } \\
\text { Genus }\end{array}$ & Reference & $\begin{array}{l}\text { Order } \\
\text { Family } \\
\text { Genus }\end{array}$ & Reference & $\begin{array}{l}\text { Order } \\
\text { Family } \\
\text { Genus }\end{array}$ & Reference \\
\hline Scrophulariales & & Holmskioldia & Pedersen 2000 & Rhynchocorys & Jimenez and Riguera 1994 \\
\hline Acanthaceae & & Isanthus & Pedersen 2000 & Siphonostegia & He et al. 1991 \\
\hline Acanthus & Jimenez and Riguera 1994 & Lamium & Pedersen 2000 & Paulowniaceae & \\
\hline Aphelandra & Hegnauer 1989 & Leonotis & Pedersen 2000 & Paulownia & Hegnauer 1990 \\
\hline Asystasia & Hegnauer 1989 & Leonurus & Jimenez and Riguera 1994 & Pedaliaceae & \\
\hline Avicennia & Scogin 1992 & Leucophae & Pedersen 2000 & Harpagophytum & Hegnauer 1990 \\
\hline Barleria & Chen et al. 1998 & Leucosceptrum & Hegnauer 1989 & Sesamum & Hegnauer 1990 \\
\hline Crossandra & Hegnauer 1989 & Marrubium & Jimenez and Riguera 1994 & Rogeria & Potterat et al. 1991 \\
\hline Hemigraphis & Hegnauer 1989 & Melittis & Pedersen 2000 & Phrymaceae & \\
\hline Hygrophila & Hegnauer 1989 & Molucella & Pedersen 2000 & Lancea & Su et al. 1999 \\
\hline Mendoncia & Scogin 1992 & Nepeta & Akbay et al. 2002 & Plantaginaceae & \\
\hline Pseuderanthemum & Hegnauer 1989 & Oxera & Grayer and De Kok 1998 & Callitriche & Scogin 1992 \\
\hline Ruellia & Hegnauer 1989 & Peronema & Pedersen 2000 & Antirrhinum & Franzyk et al. 1998 \\
\hline Strobilanthes & Hegnauer 1989 & Phlomis & Jimenez and Riguera 1994 & Digitalis & Hegnauer 1990 \\
\hline Thunbergia & Scogin 1992 & Physostegia & Pedersen 2000 & Globularia & Scogin 1992 \\
\hline Bignoniaceae & & Pogostemon & Pedersen 2000 & Gratiola & Rothenburger and Haslinger 1994 \\
\hline Barnettia & Kanchanapoom et al. 2002 & Premna & Pedersen 2000 & Hippuris & Scogin 1992 \\
\hline Campsis & Jimenez and Riguera 1994 & Prostanthera & Pedersen 2000 & Kickxia & Amer 1993 \\
\hline Deplanchea & Jimenez and Riguera 1994 & Pseuderemostachys & Pedersen 2000 & Lagotis & Jimenez and Riguera 1994 \\
\hline Fernandoa & Kanchanapoom et al. 2001 & Scutellaria & Pedersen 2000 & Penstemon & Hegnauer 1990 \\
\hline Jacaranda & Hegnauer 1989 & Sideritis & Pedersen 2000 & Plantago & Hegnauer 1990 \\
\hline Markhamia & Kernan et al. 1998 & Stachys & Hegnauer 1989 & Scoparia & von Poser et al. 1996 \\
\hline Millingtonia & Hase et al. 1995 & Stenogyne & Pedersen 2000 & Veronica & Tomassini et al. 1995 \\
\hline Newbouldia & Gafner et al. 1997 & Symphorema & Scogin 1992 & Scrophylariaceae & \\
\hline Rehmannia & Hegnauer 1990 & Tectona & Pedersen 2000 & Buddleja & Hegnauer 1989 \\
\hline Tecoma & Hegnauer 1989 & Tetraclea & Pedersen 2000 & Nuxia & Jensen et al. 1998 \\
\hline Byblidaceae & & Teucrium & Jimenez and Riguera 1994 & Oreosolen & Yu et al. 1996 \\
\hline Byblis & this study & Westringia & Pedersen 2000 & Scrophularia & Hegnauer 1990 \\
\hline Calceolariaceae & & Lentibulariaceae & & Selago & Scogin 1992 \\
\hline Calceolaria & Hegnauer 1990 & Pinguicula & Scogin 1992 & Verbascum & Hegnauer 1990 \\
\hline Gesneriaceae & & Utricularia & Damtoft et al. 1994 & Stilbaceae & \\
\hline Aeschynanthus & Jensen 1996 & Martyniaceae & & Halleria & Hegnauer 1990 \\
\hline Codonanthe & Jensen 1996 & Proboscidea & Hegnauer 1990 & Retzia & Scogin 1992 \\
\hline Columnea & Jensen 1996 & Myoporaceae & & Stilbe & Scogin 1992 \\
\hline Conandron & Hegnauer 1989 & Eremophila & Hegnauer 1990 & Tetrachondraceae & \\
\hline Gesneria & Jensen 1996 & Oleaceae & & Polypremum & Scogin and Romo-Contreras 1992 \\
\hline Lysionotus & Liu et al. 1998 & Abeliophyllum & Yamamoto et al. 1998 & Tetrachondra & Jensen 2000 \\
\hline Mitraria & Cardenas et al. 1992 & Fontanesia & Damtoft et al. 1995 & Verbenaceae & \\
\hline Nautilocalyx & Jensen 1996 & Forsythia & Hegnauer 1990 & Duranta & Takeda et al. 1995 \\
\hline Peltanthera & Jensen 2000 & Fraxinus & Shen et al. 1993 & Junellia & Franzyk et al. 2000 \\
\hline Streptocarpus & Jensen 1996 & Jasminum & Jimenez and Riguera 1994 & Lantana & Hegnauer 1990 \\
\hline Lamiaceae & & Ligustrum & Hegnauer 1990 & Lippia & Hegnauer 1990 \\
\hline Achyrospermum & Pedersen 2000 & Olea & Hegnauer 1990 & Petrea & Hegnauer 1990 \\
\hline Aegiphila & Pedersen 2000 & Osmanthus & Hegnauer 1990 & Stachytarpheta & Rodriguez and Castro 1996 \\
\hline Ajuga & Hegnauer 1989 & Phillyrea & Tattini et al. 2000 & Verbena & Hegnauer 1990 \\
\hline Anisomeles & Pedersen 2000 & Picconia & Damtoft et al. 1997 & Verbenoxylum & von Poser et al. 1998 \\
\hline Ballota & Pedersen 2000 & Syringa & Hegnauer 1990 & unassigned & \\
\hline Betonica & Pedersen 2000 & Orobanchaceae & & Icacinaceae & \\
\hline Callicarpa & Pedersen 2000 & Agalinis & von Poser et al. 1996 & Cassinopsis & Rasoanaivo et al. 1989 \\
\hline Caryopteris & Pedersen 2000 & Bartsia & Cuendet et al. 1999 & Asterales & \\
\hline Chloanthes & Scogin 1992 & Brandisia & Jimenez and Riguera 1994 & Asteraceae & \\
\hline Clerodendrum & Hegnauer 1990 & Castilleja & Hegnauer 1990 & Echinacea & Jimenez and Riguera 1994 \\
\hline Colquhounia & Pedersen 2000 & Cistanche & Hegnauer 1990 & Campanulaceae & \\
\hline Comatosphace & Pedersen 2000 & Cordylanthus & Justice et al. 1992 & Craterocapsa & van Heerden et al. 2002 \\
\hline Cornutia & Pedersen 2000 & Euphrasia & Ersoz et al. 2000 & Rosales & \\
\hline Dicrastylis & Pedersen 2000 & Lamourouxia & Hegnauer 1990 & Cucurbitaceae & \\
\hline Faradaya & Grayer and De Kok 1998 & Monochasma & Hegnauer 1990 & Momordica & Jimenez and Riguera 1994 \\
\hline Galeopsis & Hegnauer 1989 & Orobanche & Hegnauer 1990 & Magnoliales & \\
\hline Geunsia & Pedersen 2000 & Orthocarpus & Hegnauer 1990 & Magnoliaceae & \\
\hline Gmelina & Pedersen 2000 & Pedicularis & Jimenez and Riguera 1994 & Magnolia & Tsuruga et al. 1991 \\
\hline Hemiandra & Pedersen 2000 & Phtheirospermum & Hegnauer 1990 & & \\
\hline
\end{tabular}

sented in Table 1, are assigned according to data verified recently by Xiong et. al. (1996). All compounds found are new for the genus Byblis and the family Byblidaceae and they appear to be very helpful (especially acteoside) chemotaxonomical characters for solving problems of systematics of those taxa discussed below.

The genus Byblis has been of controversial systematic placement since its discovery. A number of authors (e.g. Planchon 1848) supposed a proximity to Droseraceae ma- inly due to the presence of glandular trichomes on the leaf surface. But as already pointed out by Diels (1906), the gland structures of Byblis and Drosera (or indeed any member of Nepenthales) are fundamentally different. An affinity to Roridula, essentially inspired by a common placement in Droseraceae, was assumed for similar reasons (Domin 1922) and can likewise be discounted due to ultrastructural differences. Similarities in floral structure already mentioned by Planchon (1848) led a large number of 
authors (cf. Diels 1906) to assume an affinity of Byblis to Pittosporaceae. But missing resin ducts, different ovule structure and the stalked glands that lack any equivalent in Pittosporaceae separate Byblis from the latter family. A "sympetalous" ovule structure in combination with the insect-capturing habit inspired Lang (1901) to compare Byblis with Lentibulariaceae, but the very weak sympetaly of the spurless flowers (always bilabiate and spurred in Lentibulariaceae), lacking reduction in the androeceum (two stamens and no staminodes in L.) and the septate ovary (free central in L.) clearly indicate otherwise. The presence of iridoid compounds in Byblidaceae (positive Ehrlich test, Gibbs 1974) does, however, suggest a placement in Asteridae.

Gene sequence homology comparisons (rbcL: Albert et al. 1992, 18S rRNA: Conran \& Dowd 1993) support an Asterid placement of Byblidaceae clearly separate from Droseraceae (Nepenthales, "Caryophyllales s.lat."), Roridulaceae (Ericales), and Pittosporaceae (Araliales, Apiales), and inclusion in a common monophyletic clade with Lamiaceae, Scrophulariaceae, and Lentibulariaceae comprising the order Scrophulariales (syn. Lamiales, Bignoniales). This placement was more recently confirmed by homology comparisons of six chloroplast DNA markers (Bremer et al. 2002).

Although the initial enthusiasm about the systematic usefulness of phytochemical (particularly flavonoid) characters was largely disappointed in past decades, some classical examples of characteristic secondary metabolites in selected taxonomic contexts (betalains in Caryophyllales, glucosinolates in Capparales, seed coat phytomelans in Asparagales) clearly demonstrate the validity of the chemotaxonomic concept. Recently, some phylogenetic lineages established primarily on the basis of gene sequence homology comparison have been substantiated by phytochemical data, e.g. in the case of Nepenthales, in which the majority of families (Polygonaceae, Plumbaginaceae, Droseraceae, Nepenthaceae, Drosophyllaceae, Dioncophyllaceae, Ancistrocladaceae) contain acetogenic quinones like plumbagin (Schlauer 1997).

In this context it is remarkable that acteoside (verbascoside, kusaginin) was established as a characteristic constituent of Scrophulariales (Scogin 1992). While other caffeoyl-dihydroxyphenethyl glycosides have been identified in a number of not closely related families throughout the plant kingdom (Hegnauer 1990; Jimenez and Riguera 1994; Wada et al. 1995, Braca et al. 2001), acteoside has so far been detected in only five genera not belonging to Scrophulariales, viz. Cassinopsis, Craterocapsa, Echinacea, Magnolia, and Momordica. On the other hand, all families of Scrophulariales investigated so far did contain at least one genus yielding acteoside (cf. Table 2).

Because of the obvious chemosystematic value of acteoside, its identification in Byblis liniflora, as reported in this paper, is of primary importance considering the systematic placement of Byblidaceae. It fully supports a placement in order Scrophulariales and subclass Asteridae and confirms corresponding hypotheses based on gene sequence homology. Like in Nepenthales this is another example for the usefulness of chemotaxonomy especially in cases where morphological and ultrastructural characters are ambiguous or misleading.

\section{ACKNOWLEDGEMENTS}

This work was supported by grant No. 6 P05F 00813 from the State Committee for Scientific Research, Poland (granted to J.B.) and grant No. SCHL 561/1-1 from the Deutsche Forschungsgemeinschaft (granted to J.S.). The part of preparative work was performed by Dorota Krysztopa as a part of the work for her M.Sc. degree followed at the Department of Pharmaceutical Botany in Poznań.

\section{LITERATURE CITED}

AKBAY P., CALIS I., UNDEGER U., BASARAN N., BASARAN A.A. 2002. In vitro Immunomodulatory Activity of Verbascoside from Nepeta ucrainica L. Phytotherapy Research 16: 593-595.

ALBERT V.A., WILLIAMS S.E., CHASE M.W. 1992. Carnivorous Plants: Phylogeny and Structural Evolution. Science 257: 1491-1495.

AMER A.A.M. 1993. Glycosides of Kickxia heterophylla (Schousb.) Dandy in Andrews. Alexandria J. of Pharmaceutical Sciences 7: 58-61

BRACA A., DE TOMMASI N., DI BARI L., PIZZA C., POLITI M., MORELLI I. 2001. Antioxidant Principles from Bauhinia tarapotensis. J. Nat. Prod. 64: 892-895.

BREMER B., BREMER K., HEIDARI N., ERIXON P., OLMSTEAD R.G., ANDERBERG A.A., KALLERSJO M., BARKHORDARIAN E. 2002. Phylogenetics of Asterids Based on 3 Coding and 3 Non-Coding Chloroplast DNA Markers and the Utility of Non-Coding DNA at Higher Taxonomic Levels. Molecular Phylogenetics and Evolution 24: 274-301.

BUDZIANOWSKI J. 1995. Naphthoquinones of Drosera spathulata from in vitro cultures. Phytochemistry 40: 1145-1148.

BUDZIANOWSKI J., SKRZYPCZAK L. 1995. Phenylpropanoid esters from Lamium album flowers. Phytochemistry 38: 997-1002 .

CARDENAS L.C., RODRIGUEZ J., RIGUERA R., CHAMY M.C. 1992. Mitrariosides Five Bitter Labdane Glycosides from Mitraria coccinea Gesneriaceae. Liebigs Annalen der Chemie 1992: 665-668.

CHEN J.L., BLANC P., STODDART C.A., BOGAN M., ROZHON E.J., PARKINSON N., YE Z., COOPER R., BALICK M., NANAKORN W., KERNAN M.R. 1998. New Iridoids from the Medicinal Plant Barleria prionitis with Potent Activity Against Respiratory Syncytial Virus. J. Nat. Prod. 61: 1295$-1297$.

CONRAN J.G., DOWD J.M. 1993. The Phylogenetic Relationships of Byblis and Roridula (Byblidaceae-Roridulaceae) Inferred from Partial 18S Ribosomal RNA Sequences. Pl. Syst. Evol. 188: 73-86.

CONRAN J.G., HOUBEN A., LOWRIE A. 2002a. Chromosome numbers in Byblidaceae. Australian J. Bot. 50: 583-586.

CONRAN J.G., LOWRIE A., MOYLE-CROFT J. 2002b. A Revision of Byblis (Byblidaceae) in South-Western Australia. Nuytsia 15: 11-19.

CUENDET M., POTTERAT O., HOSTETTMANN K. 1999. Iridoid Glucosides, Phenylpropanoid Derivatives and Flavonoids from Bartsia alpina. Pharmaceut. Biol. 37: 318-320.

DAMTOFT S., FRANZYK H., JENSEN S.R. 1995. Biosynthesis of Secoiridoids in Fontanesia. Phytochemistry 38: 615-621.

DAMTOFT S., FRANZYK H., JENSEN S.R. 1997. Iridoid Glucosides from Picconia excelsa. Phytochemistry 45: 743-750.

DAMTOFT S., JENSEN S.R., THORSEN J., MOLGARD P., OLSEN C.E. 1994. Iridoids and Verbascoside in Callitrichaceae, Hippuridaceae and Lentibulariaceae. Phytochemistry 36: 927$-929$.

DEBRAUWER L., MAILLARD C., VIDAL-OLLIVIER E., LAGER M., SALMONA G., AFZAL-RAFFI Z. 1989. Study in 
the chemical constituents of Plantago cynops L. and antibacterial evaluation of verbascoside. Pharm. Acta Helv. 64: 183-187.

DIELS L. 1906. Droseraceae in Engler A., Das Pflanzenreich vol. 26, Engelmann, Lepzig.

DOMIN K. 1922. Byblidaceae: A New Archichlamydeous Family. Acta Bot. Bohemica 1: 3-4.

ERSOZ T., BERKMAN M.Z., TASDEMIR D., IRELAND C.M., CALIS I. 2000. An Iridoid Glucoside from Euphrasia pectinata. J. Nat. Prod. 63: 1449-1450.

FESSLER A. 1982. Fleischfressende Pflanzen für Haus und Garten. Kosmos, Stuttgart.

FRANZYK H., FREDERIKSEN S.M., JENSEN S.R. 1998. Synthesis of Antirrhinolide, a New Lactone from Antirrhinum majus. Eur. J. Org. Chem. 8: 1665-1668.

FRANZYK H., JENSEN S.R., OLSEN C.E., QUIROGA J.M. 2000. A 9-Hydroxyiridoid Isolated from Junellia seriphioides (Verbenaceae). Org. Lett. 2: 699-700.

GAFNER S., WOLFENDER J.L., NIANGA M., HOSTETTMANN K. 1997. Phenylpropanoid Glycosides from Newbouldia laevis Roots. Phytochemistry 44: 687-690.

GIBBS R.D. 1974. Chemotaxonomy of Flowering Plants, vol. III, McGill-Queen's University Press, Montreal-London.

GRAYER R.J., DE KOK R.P.J. 1998. Flavonoids and Verbascoside as Chemotaxonomic Characters in the Genera Oxera and Faradaya (Labiatae). Biochemical Syst. Ecol. 26: 729-741.

HARBORNE J.B. 1984. Phytochemical methods. A guide to modern techniques of plant analysis. Chapman and Hall, London-New York-Tokyo-Melbourne-Madras.

HASE T., KAWAMOTO Y., OHTANI K., KASAI R., YAMASAKI K., PICHEANSOONTHON C. 1995. Cyclohexylethanoids and related glucosides from Millingtonia hortensis. Phytochemistry 39: 235-241.

HE Z.D., CAO Y.X., YANG C.R. 1991. Chemical and Pharmacognostic Studies on Siphonostegia chinensis. Acta Botanica Yunnanica 13: 197-204.

HEGNAUER R. 1989-1990. Chemotaxonomie der Pflanzen, vols. VIII \& IX. Birkhäuser, Basel. (and literature cited therein)

HUTCHINSON J. 1959. The Families of Flowering Plants vol. 1 Dicotyledons, 2. ed. Clarendon, Oxford.

HUXLEY A., (ed.). 1992. Dictionary of Gardening. The Stockton Press, New York.

JENSEN S.R. 1996. Caffeoyl Phenylethanoid Glycosides in Sanango racemosum and in the Gesneriaceae. Phytochemistry 43: 777-783.

JENSEN S.R. 2000. Chemical Relationships of Polypremum procumbens, Tetrachondra hamiltonii and Peltanthera floribunda. Biochem. Syst. Ecol. 28: 45-51.

JENSEN S.R., RAVNKILDE L., SCHRIPSEMA J. 1998. Unedoside Derivatives in Nuxia and their Biosynthesis. Phytochemistry 47: 1007-1011.

JIMENEZ C., RIGUERA R. 1994. Phenylethanoid Glycosides in Plants: Structure and Biological Activity. Nat. Prod. Rep. 11: 591-606.

JIMENEZ C., RIGUERA R. 1994. Phenylethanoid Glycosides in Plants: Structure and Biological Activity. Natural Product Reports 11: 591-606. (and literature cited therein).

JUNIPER B.E., ROBINS R.J., JOEL D.M. 1989. The Carnivorous Plants. Academic Press, London.

JUSTICE M.R., BAKER S.R., STERMITZ F. 1992. C-8 Epimeric Iridoid Glycosides of Cordylanthus Scrophulariaceae Species. Phytochemistry 31: 2021-2026.

KANCHANAPOOM T., KASAI R., YAMASAKI K. 2001. Lignan and Phenylpropanoid Glycosides from Fernandoa adenophylla. Phytochemistry 57: 1245-1248.

KANCHANAPOOM T., KASAI R., YAMASAKI K. 2002. Phenolic glycosides from Barnettia kerrii. Phytochemistry 59: 565-570.

KERNAN M.R., AMARQUAYE A., CHEN J.L., CHAN J., SESIN D.F., PARKINSON N., YE Z., BARRETT M., BALES
C., STODDART C.A., SLOAN B., BLANC P., LIMBACH C., MRISHO S., ROZHON E.J. 1998. Antiviral Phenylpropanoid Glycosides from the Medicinal Plant Markhamia lutea. J. Nat. Prod. 61: 564-570.

KOBAYASHI H., OGUCHI H., TAKIZAWA N., MIYASE T., UENO A., USMANGHANI K., AHMAD M. 1987. New Phenylethanoid Glycosides from Cistanchoe tubulosa (Screnk) Hook. f.l. Chem. Chem. Pharm. Bull. 35: 3309-3314.

KUKUŁCZANKA K. 1991. Micropropagation and in vitro germplasm storage of Droseraceae. Bot. Gard. Micropropagation News 1: 38-42.

KUKUŁCZANKA K., BUDZIANOWSKI J. 2002. Dionaea muscipula Ellis (Venus fly-trap): In vitro culture and production of secondary metabolites. In: Nagata T., Ebizuka Y. (eds) Biotechnology in Agriculture and Forestry. Vol.51, Medicinal and Aromatic Plants XII, Chapter IV, Springer Verlag, Berlin-Heidelberg, pp. 50-74.

LANG F.X. 1901. Untersuchungen über Morphologie, Anatomie und Samenentwicklung von Polypompholyx und Byblis gigantea. Flora 88: 179-206.

LIU Y., WAGNER H., BAUER R. 1998. Phenylpropanoids and Flavonoid Glycosides from Lysionotus pauciflorus. Phytochemistry 48: 339-343.

LOWRIE A. 1998. Carnivorous Plants of Australia. University of Western Australia Press, Melbourne.

LOWRIE A., CONRAN J.G. 1998. A taxonomic revision of the genus Byblis (Byblidaceae) in northern Australia. Nuytsia 12: 59-74.

MABRY T.J., MARKHAM K.R., THOMAS M.B. 1970. The Systematic Identifcation of Flavonoids. Springer Verlag, New York.

MIYASE T., KOIZUMI A., UENO A., TADATAKA N., NORO T., KUROYANAGI M., FUKUSHIMA S., AKIYAMA Y., TAKEMOTO Y. 1982. Studies on the acyl glucosides from Leucosceptrum japonicum. Chem. Pharm. Bull. 30: 2732-2737.

MURASHIGE T., SKOOG F. 1962. A revised medium for rapid growth and bio-assays with tobacco cultures. Physiol. Plant. 15: 473-497.

NISHIMURA H., SASAKI H., INAGAKI N., CHIN M., MITSUHASHI H. 1991. Nine phenethyl alcohol glycosides from Stachys sieboldii. Phytochemistry 30: 965-969.

PEDERSEN J.A. 2000. Distribution and Taxonomic Implications of some Phenolics in the Family Lamiaceae Determined by ESR Spectroscopy. Biochem. Syst. Ecol. 28: 229-253.

PIETROPAOLO J., PIETROPAOLO P. 1996. Carnivorous Plants of the World. Timba Press, Portland Oregon.

PLANCHON J.E. 1848. Sur la famille des Droséracées. Ann.sci. nat.3.sér.Bot.IX 79-90, 305-307.

POTTERAT O., SAADOU M., HOSTETTMANN K. 1991. Iridoid Glucosides from Rogeria adenophylla. Phytochemistry 30: 889-892.

RASOANAIVO P., RATSIMAMANGA-URVERG S., MESSANA I., DE VINCENTE Y., GALEFFI C. 1990. Cassinopin, a Kaempferol Trirhamnoside from Cassinopsis madagascariensis. Phytochemistry 29: 2040-2043.

REINERT R.A., MOHR H.C. 1967. Propagation of Cattleya by tissue culture of lateral bud meristems. Proc. Am. Soc. Hort. 91: 664-671.

RODRIGUEZ S.M., CASTRO O. 1996. Chemical and Pharmacological Evaluation of Stachytarpheta jamaicensis (Verbenaceae). Revista de Biologia Tropical 44 (2A): 353-359.

ROTHENBURGER J., HASLINGER E. 1994. Caffeic Acid Glycoside Esters from Gratiola officinalis L. Liebigs Ann. Chem. 1994: 1113-1116.

SCHLAUER J. 1997. "New" Data Relating to the Evolution and Phylogeny of Some Carnivorous Plant Families. Carniv. Pl. Newslett. 26: 34-38.

SCOGIN R. 1992. The Distribution of Acteoside among Angiosperms. Biochem. Syst. Ecol. 20: 477-480. (and literature cited therein) 
SCOGIN R., ROMO-CONTRERAS V. 1992. Familial Assignment of Polypremum: Evidence from Phenolic Chemistry. Biochem. Syst. Ecol. 20: 787-788.

SHEN Y.C., CHEN C.H., LEE K.H. 1993. Secoiridoid Dilactones from Fraxinus uhdei. Phytochemistry 33: 1531-1533.

SHIMOMURA H., SASHIDA Y., ADACHI T. 1987. Phenolic glucosides from Prunus grayana. Phytochemistry 26: 249-251.

SLACK A. 1985. Karnivoren: Biologie und Kultur der Insectenfangenden Pflanzen. Ulmer, Stuttgart.

SLOLEY B.D., URICHUK L.J., TYWIN C., COUTTS R.T., PANG P.K.T., SHAN J.J. 2001. Comparison of Chemical Components and Antioxidants Capacity of Different Echinacea Species. J. Pharm. Pharmacol. 53: 849-857.

SU B., ZHU Q., GAO K., YUAN C., JIA Z. 1999. Lignan and Phenylpropanoid Glycosides from Lancea tibetica and Their Antitumor Activity. Planta Med. 65: 558-561.

TAKEDA Y., MORIMOTO Y., MATSUMOTO T., OGIMI C., HIRATA E., TAKUSHI A., OTSUKA H. 1995. Iridoid glucosides from the leaves and stems of Duranta erecta. Phytochemistry 39: 829-833.

TATTINI M., GRAVANO E., PINELLI P., MULINACCI N., ROMANI A. 2000. Flavonoids Accumulate in Leaves and Glandular Trichomes of Phillyrea latifolia Exposed to Excess Solar Radiation. New Phytologist 148: 69-77.

TOMASSINI L., BRKIC D., SERAFINI M., NICOLETTI M. 1995. Constituents of Veronica hederifolia and Veronica polita. Fitoterapia 66: 382.

TSURUGA T., EBIZUKA Y., NAKAJIMA J., CHUN Y.T., NOGUCHI H., IITAKA Y., SANKAWA U. 1991. Biologically active constituents of Magnolia salicifolia: inhibitors of indu- ced histamine release from rat mast cells. Chem. Pharm. Bull. 39: 3265-3271.

VAN HEERDEN F.R., VILJOEN A.M., MOHOTO S.P. 2002. A Phytochemical Investigation of Craterocapsa tarsodes, a Plant Used for the Treatment of Epilepsy by the Northern Sotho People of South Africa. South African J. Bot. 68: 77-79.

Von Poser G., Henriques A.T., Schripsema J., Jensen S.R. 1996. Iridoids and Phenylpropanoid Glucosides from Agalinis communis (Cham. \& Schlechtd.) D'Arcy and Scoparia ericacea Cham. (Scrophulariaceae). Rev. Brasil. Farmac. 77: 134-136.

VON POSER G., SCHRIPSEMA J., OLSEN C.E., HENRIQUES A.T., JENSEN S.R. 1998. 2'-Apiosylgardoside, an Iridoid Glucoside from Verbenoxylum reitzii. Phytochemistry 49: 1471-1473.

WADA H., SHIMIZU Y., TANAKA N., CAMBIE R.C., BRAGGINS J.E. 1995. Chemical and Chemotaxonomical Studies of Ferns. LXXXVII. Constituents of Trichomanes reniforme. Chem. Pharm. Bull. 43: 461-465.

XIONG Q., KADOTA SH., TANI T., NAMBA T. 1996. Antioxidative effects of phenylethanoids from Cistanche deserticola. Chem. Pharm. Bull. 19: 1580-1585.

YAMAMOTO H., YOSHIDA K., KONDO Y., INOUE K. 1991. Production of Cornoside in Abeliophyllum distichum Cell Suspension Cultures. Phytochemistry 48: 273-277.

YU G.P., LI X.C., WANG Y.F., LIU Y.Q., YANG C.R. 1996. Spermicidal Saponins from Oreosolen wattii. Acta Botanica Yunnanica 18: 229-233.

ZENK M.H., FÜHRBRINGER M., STEGLICH W. 1969. Occurrence and distribution of 7-methyljuglone and plumbagin in the Droseraceae. Phytochemistry 8: 2199-2200. 